\title{
Application Research of SPOC-Based Blended Teaching in the Cultivation of Newcomers of the Times in the University: Taking "Web Front-End Technology Foundation" Course as an Example
}

\author{
Jinxin Chen, Decheng Zhang \\ School of Information Engineering, Yancheng Teachers University, Yancheng, China \\ Email: chenjx@yctu.edu.cn, zhangdc@yctu.edu.cn
}

How to cite this paper: Chen, J. X., \& Zhang, D. C. (2021). Application Research of SPOC-Based Blended Teaching in the Cultivation of Newcomers of the Times in the University: Taking "Web Front-End Technology Foundation" Course as an Example. Open Journal of Social Sciences, 9, 182-191.

https://doi.org/10.4236/jss.2021.911015

Received: October 22, 2021

Accepted: November 22, 2021

Published: November 25, 2021

Copyright $\odot 2021$ by author(s) and Scientific Research Publishing Inc. This work is licensed under the Creative Commons Attribution International License (CC BY 4.0).

http://creativecommons.org/licenses/by/4.0/

\begin{abstract}
Adhering to the fundamental goal of building morality and cultivating people, systematic, all-round, and long-term ideological and political education is the fundamental task of colleges and universities to cultivate new people with faith, sentiment, and responsibility. According to the requirements of educating people and educating talents of the newcomers, this paper constructs an ideological and political SPOC course for the newcomers in the computer-related professional to learn independently, using a blended teaching method based on flipped classrooms, taking advantage of the interaction and growth archive recording functions of the SPOC platform, and carrying out multiple evaluation on students through a mixed teacher team, accurately depicting students' ideological and political level, academic cognition and skills, and professional accomplishment, it realizes the unity of value shaping, knowledge imparting and ability cultivation.
\end{abstract}

\section{Keywords}

Ideological and Political Theory Curriculum, SPOC Course, Blended Teaching, Newcomers of the Times

\section{Background of the Study Heading}

The newcomers of the times are not only a historical category, but also have a strong meaning of the times. The responsibilities given to the youth of the times are not the same in each historical period (Fu \& Xu, 2019). On October 18, 2017, 
General Secretary Xi Jinping clearly stated in the report of the 19th National Congress of the Communist Party of China that "it is necessary to focus on cultivating newcomers of the times who are responsible for national rejuvenation" (Xi, 2017). On April 19, 2021, during an inspection tour at Tsinghua University, General Secretary Xi Jinping called on young people to "make great ambitions, make great virtues, become talents, and assume great responsibilities, and strive to become newcomers of the times who can serve as the important task of national rejuvenation" (Xi, 2021). As the goal of talent training in schools at all levels, the newcomers of the times have attracted the attention of many educators. As of August 15, 2021, a subject search has been conducted on CNKI with the keyword "Newcomers of the Times", and there are 1874 journal articles in total. Among them, 553 articles were published in core journals and CSSCI journals. Through the visual analysis of HowNet, 7 articles were published in 2017, 88 articles in 2018, 177 articles in 2019, 161 articles in 2020, and 193 articles estimated in 2021, showing an overall upward trend.

\section{Putting Forward a Question}

Newcomers of the times are those who have lofty ideals and strong abilities, who can take on the task of rejuvenating the Chinese nation and fulfill the mission of the times entrusted by history. Ideals, abilities, and responsibility are the main characteristics of the newcomers of the times. Contemporary college students are the main body of the "newcomers of The Times". They need to have firm ideals and beliefs, strong sense of responsibility, excellent skills and unremitting spirit of struggle for their historical mission and social responsibility.

How to cultivate newcomers of the times? What are the cultivation paths? Many scholars have done research from different levels. Deng (2021) and Tian (2021) studied the background, connotation and cultivation path of the newcomers of the times. Xing (2021) strengthened the cultivation of newcomers of the era through activities such as "Red Boat Spirit", Liu (2020) through "Labor Education", and Hou (2020) through "Gentleman Personality" and other activities.

The training goals and requirements of different majors in universities are different, but the overall goals of educating people and educating talents are the same. Computer professional courses are highly practical, fast in technology update, and difficult to learn in courses. It is also difficult to find employment after graduation, which affects students' learning enthusiasm and professional recognition. As a course teacher of computer majors in colleges and universities, how to cultivate ideal, capable, and responsible newcomers in the teaching process? Few related research articles were found in the relevant retrieval of CNKI. This article takes the course of "Web Front-end Technology Foundation" as an example, systematically designs ideological and political elements, and deeply integrates with professional teaching, and actively carries out reforms in teaching methods and evaluation systems to promote the high-quality training of newcomers in the times. 


\section{Research Methods}

1) Literature method: Reading, analyzing, and collating relevant documents on topics such as newcomers of the times, ideological and political theory curriculum, SPOC, blended teaching, flipped classroom, and Web front-end technology in CNKI, to provide evidence and research methods for research topics, and clarify Subject research direction.

2) Action Research Method: Guided by virtue-building, blended learning theory, etc., a variety of research methods and techniques are used comprehensively to construct a goal-oriented curriculum ideological and political SPOC blended teaching mode.

3) Practice method: The constructed teaching model is applied to actual teaching, and the shortcomings are found and corrected. Finally, complete content and organizational editing before formatting.

\section{Purposes of Research}

Explore and improve the SPOC-based blended teaching method, which based on fostering virtue and goal-oriented, and fully integrated with curriculum ideology and politics, in order to provide a teaching reform demonstration case for how to train newcomers in the times of computer-related majors.

\section{Process of Research}

\subsection{Course Analysis}

"Web front-end Technology Foundation" is a required course for computer related majors. The goal of the course is to train students to understand and abide by the professional ethics and norms of Web front-end development, and to achieve the ability of website development with commercial design characteristics and enterprise application level. In order to be the gatekeeper of website content, a very high level of political literacy is required, and students need to be trained to have the correct ideals and beliefs, value orientation, political literacy, social responsibility and international vision; in addition, the website content needs to be in the form of appropriate media, strict logical method and precise front-end technology for performance, need to have a more comprehensive professional quality, need to train students to have good humanistic quality, artistic accomplishment and aesthetic ability, and cultivate students to have teamwork spirit, critical thinking ability, pioneering and enterprising and the pursuit of innovation ability, need to guide students to continue to learn independently, and then adapt to the needs of society and enterprises for the cultivation of front-end talents.

\subsection{Constructing SPOC Resources of Ideological and Political Courses for Educating People and Talents}

Curriculum ideology and politics is a new exploration in the field of ideological and political education. It penetrates Marxist standpoint, views and methods in- 
to the education and teaching of all disciplines, making ideological and political education more realistic and penetrating, and guiding value in knowledge transmission (Zhu, 2019). The essence of ideological and political curriculum is to cultivate people through virtue. The ideological and political content of the course includes political identity, family and country feelings, cultural literacy, constitutional awareness of the rule of law, moral accomplishment, etc. In popular terms, it includes responsibility and responsibility, how to behave and how to do things.

It is necessary to reform the traditional teaching content system and teaching methods in order to realize the teaching goal of establishing virtue and cultivating talents. This course takes advantage of the network platform, integrates ideological and political elements into teaching, and constructs SPOC teaching resources that are conducive to student learning, which is an effective way to break the ideological and political boring and achieve the golden course target of professional courses. SPOC teaching resources are based on the design and development of short and concise teaching micro-videos with a duration of less than ten minutes. Micro-videos have small knowledge granularity, elaborate teaching design, fine content explanation and excellent video production, making them popular teaching resources for students. In addition to the characteristics of online interaction and rich media materials, SPOC courses can also combine local culture and specific requirements of students to construct distinctive school-based teaching resources, such as jiangsuyancheng, has a red iron army culture, a green wetland culture, and white sea salt Culture, etc., as well as traditional cultures such as Huai opera and acrobatics are good ideological and political materials for educating students.

One of the important characteristics of the newcomers is innovation, and they can apply what they learn to solve practical problems, which is the lack of traditional courses. In the construction of SPOC course, the course knowledge points should be deconstructed and reorganized in an results-oriented way first, and the high challenge goal of solving problems from small to large and from point to surface can be achieved through the combination of modular micro knowledge points with systematic teaching design method. This course is designed with ideological and political leadership and practical project design, and determines four ideological and political integration points of "remembering the spirit of the iron army", "promoting traditional culture", "building a beautiful hometown", and "being a qualified front-end development engineer". And is systematically designed with the ideological and political content of the course from the aspects of mainstream thought, quality of thinking, industry requirements and professional literacy, so as to promote the synchronous development of political literacy and professional ability. The corresponding SPOC resources for this course are shown in Table 1.

\subsection{Digging Ideological and Political Information, Experiencing Education Silent}

Montessori said, "I have heard it, and I forgot; I saw it, and I remembered; I did 
Table 1. Part of the ideological and political elements and knowledge point system of the "Web front-end technology foundation" SPOC course.

\begin{tabular}{|c|c|c|}
\hline $\begin{array}{c}\text { Professional } \\
\text { Skill }\end{array}$ & $\begin{array}{l}\text { Ideological and } \\
\text { political elements }\end{array}$ & Knowledge points \\
\hline $\begin{array}{l}\text { Graphic } \\
\text { webpage }\end{array}$ & $\begin{array}{l}\text { The pictures shows } \\
\text { Yancheng }\end{array}$ & $\begin{array}{l}\text { HTML5 Image Ttags } \\
\text { CSS Border-radius } \\
\text { CSS Box-shadow and Gradients } \\
\text { CSS Transition }\end{array}$ \\
\hline $\begin{array}{l}\text { Web page } \\
\text { layout }\end{array}$ & $\begin{array}{l}\text { "People's Iron Army” } \\
\text { website homepage } \\
\text { design }\end{array}$ & $\begin{array}{l}\text { Div, Span } \\
\text { Normal Flow } \\
\text { Float } \\
\text { Position }\end{array}$ \\
\hline $\begin{array}{l}\text { Audio and } \\
\text { video page }\end{array}$ & $\begin{array}{l}\text { “China Huai Opera" } \\
\text { website "Genre Art" } \\
\text { page design }\end{array}$ & $\begin{array}{l}\text { Audio Tag } \\
\text { Basic knowledge of JavaScript } \\
\text { Functions, Objects, Events of } \\
\text { JavaScript }\end{array}$ \\
\hline $\begin{array}{l}\text { Responsive web } \\
\text { layout }\end{array}$ & $\begin{array}{l}\text { "China Huai Opera" } \\
\text { website homepage } \\
\text { reconstructed by } \\
\text { Boostrap }\end{array}$ & $\begin{array}{l}\text { Responsive design concept } \\
\text { Media query and its application } \\
\text { Desktop first layout and mobile } \\
\text { first layout } \\
\text { Basic knowledge of Boostrap } \\
\text { Boostrap Grid system } \\
\text { Boostrap General style }\end{array}$ \\
\hline
\end{tabular}

it, and I understood". The study of any course is the same, only by hands-on experience, to grasp the content of the course. Through the way of project design, the ideological and political elements are deeply integrated with the course content. The students read, collect and organize ideological and political materials in advance according to the guidance of the teacher's learning task list before class. For example, Yancheng is an old revolutionary base area, where the New Fourth Army rebuilt its military headquarters, forming a thick red culture. The New Fourth Army, also known as the "Iron Army", is an important anti-japanese armed force led by the Communist Party of China. Students check relevant texts, pictures, videos and other information on the website, watch pictures and objects at the Memorial hall of the New Fourth Army, and listen to the explanation of the commentator. Some students also visited the new Fourth Army meeting Monument of shikou Eighth Route Army in Baiju Town, Dafeng City, Yancheng, and the former site of the New Fourth Army headquarters in Tinqi Port, Funing County, to remember the revolutionary martyrs, trace the development and combat footprints of the New Fourth Army, and have a deep understanding and experience of the Iron army spirit of the New Fourth Army: "Listening to the party's command and being loyal to the party is the soul of the iron army's spirit. Serving the people and selfless dedication are the important cores of the iron army's spirit. Heroic struggle and courage are important manifestations of the iron army's spirit. Strict discipline and good work style are the important 
cornerstones of the iron army's spirit." Many students said that they must learn Web front-end technology well, promote the New Fourth Army through online platforms, and inherit the iron army culture.

\subsection{Improving Professional Quality through Blended Teaching Based on Flipped Classroom}

Horizon Report 2017 higher Education Edition of New Media Alliance points out that in the next $1-2$ years, blended learning and teaching will become the main form (Sun et al., 2017). At present, experts and scholars at home and abroad are still inconsistent in the definition of "blended teaching". Needless to say, based on the online course mix of online and offline, on the basis of online teaching resources and the premise, with flexible and varied offline learning activities for the carrier of extends and quality evaluation, has realized the depth study of the teaching goal and personalized on-demand learning, is the most important of the current hybrid in the form of teaching and learning, It is also the main way to cultivate new people.

Knowledge from understanding to application is the process of students' internalization of knowledge, and from application to expansion is the process of students' innovation. In traditional teaching, knowledge internalization is achieved through independent completion of homework after class, which is often difficult due to the lack of teacher guidance and discussion and cooperation among students. If things go on like this, students' enthusiasm for learning will be dissipated, and innovation is impossible. Practice has proved that flipped classroom and project-driven can effectively solve the problems of knowledge internalization and practical innovation. The "Web Front-end Technology Foundation" course implements a project-driven flipped classroom teaching method. The first stage is independent learning of knowledge. Teachers publish resources on the SPOC platform to provide students with project descriptions and knowledge points decomposition related resources. Students can independently complete the learning of knowledge points micro-videos, teaching courseware and other content according to the learning task list, search and organize the ideological and political materials needed for the project, and complete targeted exercises on knowledge points, teachers can understand students' autonomous learning in real time, and give timely feedback on exercises; The second stage is to solve problems in class and promote knowledge internalization. Teachers organize students to discuss and communicate, solve the problems encountered by students in independent learning, guide students to apply the knowledge points they have learned to operate skill points, optimize ideological and political materials, and then design the optimized materials through comprehensive use of skill points, collaborate with development projects and student groups to complete project development; The third stage is evaluation and development. Ideological and political teachers and counselors check the content of the website. The lecturer evaluates the technical ability and artistic performance of the 
project. Students modify the content and performance of the website based on the evaluation feedback, and carry out project expansion and innovation. The three stages effectively cultivate students' independent learning ability, scientific thinking ability, problem solving ability, collaboration ability, etc., provide the foundation and guarantee for the application and innovation of knowledge, and provide the necessary professional quality for the training of newcomers of the times.

\subsection{Recording the Growth Process of Newcomers Based on SPOC Platform}

The SPOC platform of "Web Front-end Technology Foundation" provides diversified interactive functions such as sign-in, survey, random roll call, test, homework, mutual evaluation, discussion area, etc., which is conducive to the process management of students. The test function is added to the video playback to prevent students from fake learning behaviors of brushing the video; the random point function can improve the concentration of learning; the classroom test can detect the learning effect in real time, so that timely feedback and adjustment of teaching can be achieved; the discussion area not only publishes technical discussions posting, you can also communicate on ideological and political content to jointly improve ideological understanding; the mutual evaluation function of homework provides students with opportunities to learn from each other. While improving the sense of responsibility to students, it also improves diversified learning of problem solving. The online platform will also provide teachers with learning warnings for each student's learning situation, and teachers will analyze student dynamics in a timely manner to provide targeted guidance.

\subsection{Evaluating Diversifiedly by Mixed Course Group}

The general principle of mixed teaching effect evaluation based on SPOC course is result oriented, which needs to build an evaluation system based on the standards of newcomers of the times and the goal of building morality and cultivating people, and emphasizes the unity of educating people and talents, the unity of value shaping, knowledge imparting and ability cultivation, and pays attention to the process, dynamic and continuity of evaluation, which requires a mixed curriculum team. The course team of "Web Front-end Technology Foundation" includes not only professional teachers with high professional quality, but also ideological and political teachers who check and improve political awareness, political literacy, and political level; it also includes counselors and head teachers who are familiar with the ideological dynamics of students. The mixed curriculum group evaluates students' learning from different perspectives, including the explicit achievements such as periodic homework, tests and practical works, as well as the implicit achievements such as division of learning, information literacy, way of thinking, coordination and communication ability in the learning 
process. It not only evaluates students' social responsibility and traditional cultural identity, but also evaluates students' professional ability and accomplishment, so as to ensure the high quality and high-level teaching objectives of building morality and cultivating people.

\section{Teaching Effect}

The statistical analysis of the survey data before and after the course shows that students' understanding of the course has undergone profound changes. The degree of interest in the course has changed from $47 \%$ before the study to $86.9 \%$ after the study. Job willingness changed from $67 \%$ before study to $79.8 \%$ after study; in the process of searching, collecting and sorting out the spirit of the iron army, $39.4 \%$ and $51.5 \%$ of the students have a very deep and deep understanding of the spirit of the iron army, $54.6 \%$ of the students believe that their learning spirit and sense of responsibility have been significantly improved; $78.8 \%$ of the students highly identify with Chinese traditional culture; In the retrieval and collection of traditional cultural resources, $60.6 \%$ of the students were completely able to describe the origin and core characters of traditional culture, while $33.3 \%$ were basically able to describe them; In the teaching of ideological and political elements into professional courses, $59.6 \%$ of students like it very much, $35.4 \%$ like it; in the stage web design, $70.7 \%$ of the students thought that the web page with the spirit of the Iron Army in mind was better; and $67.7 \%$ of the students believe that the standards for talents in newcomers of the times are political standards.

Through project-driven flipped classroom teaching, $42.4 \%$ of students have significantly improved their expectations of course achievement, $41.4 \%$ have improved, and $15.2 \%$ remain unchanged. In terms of the overall evaluation of the learning effect of the course, $89.9 \%$ of the students improved in independent learning ability, $73.7 \%$ in learning methods, $62.6 \%$ in knowledge application ability, 59.6\% in problem exploration and practical innovation ability, and $47.5 \%$ in ideological and political level. The top three requirements for Web front-end engineers are professional ethics and standards (92.9\%), design and development ability (88.9\%), and literature retrieval and screening ability (85.9\%).

From the above data, it can be concluded that in the goal-oriented SPOC hybrid teaching, the ideological and political elements are integrated into the whole process of professional teaching, which has a positive impact on the political awareness, professional ability, and professionalism of the newcomers in the computer-related professional era.

\section{Research Summary}

Education is a national plan and a party plan. Political stance is related to the future and destiny and the success or failure of the cause. Focusing on the fundamental task of building morality and cultivating people, with the theme of "buckle the first button in life", construct a curriculum ideological and political 
in-depth integration of ideological and political elements and professional knowledge, actively carry out result-oriented blended teaching based on curriculum ideological and political SPOC, and realize online and offline mixing, ideological and political and professional integration, heuristic teaching and task-driven mixing, knowledge learning and practical application simultaneously, effectively improve the ideological and political level, comprehensive ability and professional quality of students, which have positive significance to the cultivation of newcomers of the times.

\section{Funding}

The 2020 project of the 13th Five-Year Plan of Education Science of Jiangsu Province "Application research of Blended Teaching Mode based on SPOC Curriculum in The Cultivation of New Talents in Colleges and Universities" (C-c/ 2020/01/06); The special project of "university quality education and digital course construction" in Jiangsu colleges and universities "Research on the construction and application of computer online practice gold course" (2020jdkt073).

\section{Conflicts of Interest}

The authors declare no conflicts of interest regarding the publication of this paper.

\section{References}

Deng, Z. Q. (2021). The Scientific Connotation, Main Features and Cultivation Paths of "Newcomers of the Times"-Based on the Perspective of the Communist Youth League's Work. Chinese Youth Social Sciences, 40, 40-47.

Fu, K., \& Xu, Y. S. (2019). The Historical Context and Connotation of the Newcomers of the Times. Journal of Qiqihar University (Phi \& Soc Sci), 7, 18-21.

Hou, W. L. (2020). The Transformation and Transcendence from the Personality of a Gentleman to a Newcomer of the Times. Guangxi Social Sciences, 3, 91-95.

Liu, C. (2020). Strengthen Labor Education and Forge Newcomers of the Times. Red Flag Manuscript, 10, 38-39.

Sun, L. H., Ge, X. L., \& Chen, Z. J. (2017). The Application Prospects of Technology in Higher Education in the Future-Based on the Analysis of "Horizon Report 2017 (Higher Education Edition)”. Audio-Visual Education Research, 38, 121-128.

Tian, H. J. (2021). The Basic Connotation and Cultivation Path of "Newcomers of the Times". Social Scientist, 1, 126-130.

Xi, J. P. (2017). Decisive Victory to Build a Moderately Prosperous Society in an All-Round Way, to Win the Great Victory of Socialism with Chinese Characteristics in the New Era-A Report at the 19th National Congress of the Communist Party of China. http://www.gov.cn/zhuanti/2017-10/27/content_5234876.htm

Xi, J. P. (2021). Xi Jinping Inspected at Tsinghua University: Persist in the Goal of Building a World-Class University with Chinese Characteristics, and Contribute to the Prosperity of the Country and the Rejuvenation of the People. http://www.gov.cn/xinwen/2021-04/19/content_5600661.htm

Xing, H. H. (2021). The Jiaxing Practice of Activating the "Red Boat Spirit" Education 
Cultural Gene and Fostering Newcomers of the Times. Journal of China Education, 6, 8-14.

Zhu, F. (2019). The Clarification of the Value of Ideological and Political Courses in Colleges and the Choice of Approach. Ideological and Theoretical Education, 8, 67-72. 